Dhaka Univ. J. Sci. 60(2): 231-237, 2012 (July)

\title{
Design and Analysis of Chemotherapy and Immunotherapy Drug Scheduling Model for Cancer Tumour Treatment

\author{
Rajib Mazumder and M.S. Alam
}

Department of Applied Physics, Electronics \& Communication Engineering, Dhaka University, Dhaka-1000, Bangladesh

Received on 23. 08. 2011. Accepted for Publication on 01. 12. 2011.

\begin{abstract}
This paper presents an investigation into a mathematical model of cancer tumour growth and response with chemotherapy and immunotherapy treatments. d'Onofrio and co-workers ${ }^{[1-3]}$ developed a model to predict and control cancer tumour growth based on cell functions and effects of chemotherapy and immunotherapy. Several design objectives and constraints were used to obtain optimal drug scheduling. These included (i) maximizing tumour cell killing, (ii) tolerable drug concentration, (iii) tolerable body temperature rise and (iv) normal increase of vasculature cell at the end of treatment regime ${ }^{[1]}$. This paper, initially, implements the model in a simulation environment and then analyzes it with several drug doses that maximize killing of cancerous cells and increase normal vasculature cells during and after treatment period. Then a number of doses have been designed heuristically to improve aforementioned treatment objectives and to analyze the effects of chemotherapy and immunotherapy further. The designed doses show significant improvement in terms of cancerous cell killing with a normal recovery of vasculature cell after the treatment period. This paper also presents an investigation into parameter sensitivity of the model that shows tumour response with different model parameters and drug doses.
\end{abstract}

Keywords: Chemotherapy, Drug scheduling, Immunotherapy, Malignant cell, Vasculature cell.

\section{Introduction}

Cancer is one of the major diseases of humanity. Cancer arises from a mutation of genes which are responsible for the correct reproduction of cells. The final result is a malignancy, a tumor, which grows uncontrolled and invasive. Classic treatments contain the removal of the tumour by surgery, radiotherapy, immunotherapy and also chemotherapy, which means infusion of drugs that inhibits or stops the growth of tumor cells ${ }^{[4-5]}$. Chemotherapy, in general, affects non-tumor cells, a negative side effect, which has to be kept under control. Such therapies may be combined with additional therapies, like anti-angiogenesis, which has an effect on the blood vessel in the neighborhood of the tumor, or immunotherapy which aims at a stimulation of the patients' immune system ${ }^{[4-5]}$. Particularly for medical treatments such as chemotherapy, immunotherapy, antiangiogenic therapy, and a combination of them, time and amount of drug infusion may be crucial, since the cell population undergo complex processes. As a result mathematical Modeling, simulation, and optimization have become an indispensable ingredient of research ${ }^{[3-9]}$. This paper presents an investigation into a mathematical model of cancer tumour growth and response with chemotherapy and immunotherapy treatments.

\section{Cancer Chemotherapy Model}

The cancer tumour model developed by d'Onofrio and coworkers $^{[1-2]}$ is modification of Hahnfeldt model ${ }^{[10]}$. The model consists of two states, three control and eleven parameters in three parameter sets. It contains a combination of chemotherapy and immunotherapy. Model equations are stated below ${ }^{[3]}$ :

$\mathrm{X}_{\mathrm{o}}{ }^{\prime}(\mathrm{t})=-\mathrm{Ex}_{\mathrm{o}}(\mathrm{t}) \ln \left(\mathrm{x}_{0}(\mathrm{t}) / \mathrm{x}_{1}(\mathrm{t})\right)-\emptyset \mathrm{x}_{0}(\mathrm{t}) u_{1,}(\mathrm{t})----$

$$
\begin{aligned}
& \mathrm{X}_{1}(\mathrm{t})=\mathrm{b} \mathrm{x}_{0}(\mathrm{t})-\mu \mathrm{x}_{1}(\mathrm{t})-d \mathrm{x}_{0}(\mathrm{t})^{2 / 3} \mathrm{x}_{1}(\mathrm{t})-\gamma \mu_{0}(\mathrm{t})- \\
& \mathrm{x}_{1}(\mathrm{t})-n \mu_{1}(\mathrm{t}) \mathrm{x}_{1}(\mathrm{t})
\end{aligned}
$$

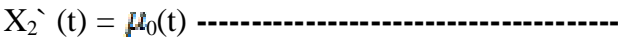

$$
\begin{aligned}
& \mathrm{X}_{3}(\mathrm{t})=\mu_{1}(\mathrm{t})
\end{aligned}
$$

Here, $\phi=$ cells killed per unit time per unit drug concentration, $\mathrm{b}=$ Vasculature cell carrying capacity, $\epsilon=$ Tumor growth rate, $\mathrm{d}=$ carrying capacity of tumour cells, $\mu=$ Vasculature cell growth factor, $\gamma=$ The mutation rate of vasculature cells, $n=$ drug decay, $\mu_{0=}$ immunotherapy dose and $\mu_{1=}$ chemotherapy dose.

Equation (1) represents tumour population $\mathrm{x}_{0}$ after the treatment regime whereas volume of vasculature cell after treatment regime is expressed by equation (2). Equation (3) and (4) represent applied immunotherapy and chemotherapy doses. Parameter sets of the model are shown in Table 1.

Table. 1. Parameter sets ${ }^{[3]}$

\begin{tabular}{|c|c|}
\hline Model parameters & Values \\
\hline$\emptyset$ & 0.1 day $^{-1}$ \\
\hline$\in$ & 0.084 day $^{-1}$ \\
\hline $\mathrm{b}$ & 0.17 day $^{-1}$ \\
\hline $\mathrm{d}$ & 0.00873 day $^{-1}$ \\
\hline$\mu$ & 0.02 day $^{-1}$ \\
\hline$\gamma$ & 0.15 day $^{-1}$ \\
\hline$n$ & 0.1 day $^{-1}$ \\
\hline $\mathrm{y}_{\max }$ & $350 \mathrm{Mg}$ \\
\hline $\mathrm{z}_{\max }$ & $450 \mathrm{Mg}$ \\
\hline $\mathrm{u}_{\max }$ & $75 \mathrm{Mg}$ \\
\hline$\vartheta_{\max }$ & $75 \mathrm{Mg}$ \\
\hline
\end{tabular}




\section{Implementation and Results}

The whole model, as stated earlier, is implemented in Matlab/Simulink ${ }^{[11]}$ environment where standard set of parameters, as indicated in Table 1 is used. Matlab/Simulink is chosen as it offers easier implementation and visualization of response of such system. It is to be noted that following constraints in relation to drug doses must be maintained while implementing the model.

Table. 2. Design constraint values ${ }^{[3]}$

\begin{tabular}{|l|c|}
\hline Design constraint & Accepted values \\
\hline $\begin{array}{l}\text { Cumulative } \\
\text { immunotherapy doses }\end{array}$ & $\leq 350 \mathrm{mg}$ \\
\hline $\begin{array}{l}\text { Cumulative chemotherapy } \\
\text { doses }\end{array}$ & $\leq 450 \mathrm{mg}$ \\
\hline
\end{tabular}

Figure 1 shows the growth of vasculature and tumour cells when no therapy is applied. Both vasculature and tumour cells show gradual increase in course of time. Initial volume of tumour is $1.2 \times 10^{4}$ and it reaches to $1.3 \times 10^{4}$ after one week which is about $10 \%$ of the initial value. In case of vasculature cell, initial volume is $1.5 \times 10^{4}$ and it reaches to $1.62 \times 10^{4}$. When no therapy is used, both tumor cell and vasculature cell volume are maximum in number. In cancer treatment, chemotherapy works on tumour and immunotherapy affects the vasculature cells those help the cancerous cells to spread. So both the cells must be reduced initially. But at the end of treatment plan, it is targeted that tumour cells are in falling trend and affected vasculature cells are in the recovery phase. Several treatment cases are tested on the model and the cases listed below:

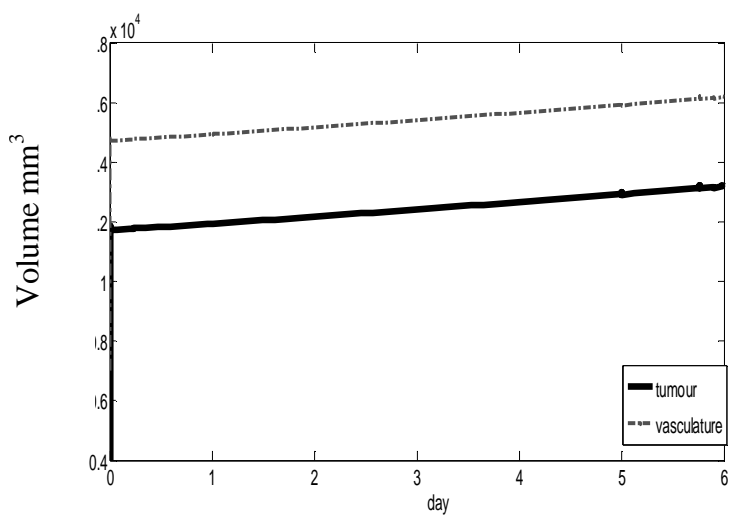

Time (day)

Fig. 1. Growth of vasculature and tumour cells without any therapy.

Case 1: High chemo dose between $4^{\text {th }}$ and $5^{\text {th }}$ day with some variations of immunotherapy.

Case 2: High chemo and immunotherapy dose for $2 \& 4$ days respectively.
Case 3: High chemo dose between after $1^{\text {st }}$ day with some variations of immunotherapy.

Case 4: High chemo dose between at the start of $4^{\text {th }}$ day with gradual increase of immunotherapy.

Case 5: High chemo dose at the start of $2^{\text {nd }}$ day with gradual increase of immunotherapy

Case 6: Maximum dose of chemotherapy is applied through the whole session.

Following sections will discuss response of each case and corresponding results.

Case 1: Figure 2 shows chemotherapy and immunotherapy drug doses and corresponding responses of tumour and vasculature cells with Case 1. Prior to treatment, volumes of tumour and vasculature cells were $12000 \mathrm{~mm}^{3}$ and $14000 \mathrm{~mm}^{3}$ respectively.

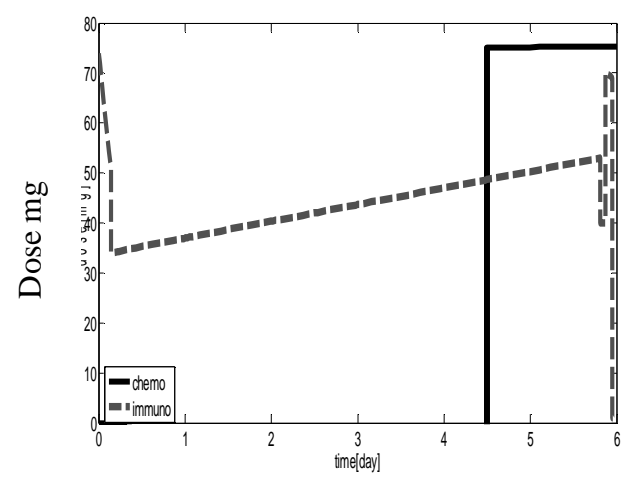

Time (day)

(a)

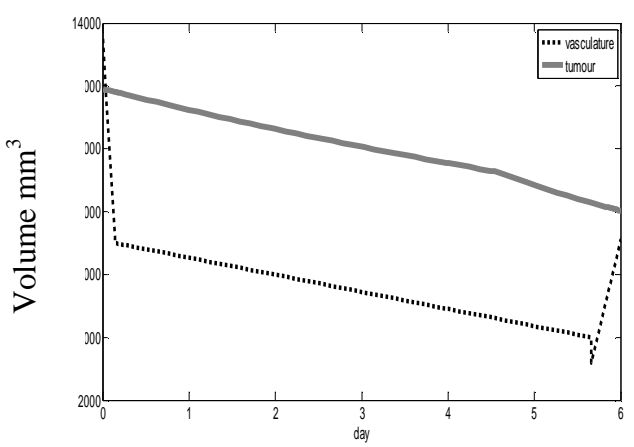

Time (day)

(b)

Fig. 2. (a) Chemotherapy and Immunotherapy drug doses, (b) Response of cells with Case 1 treatment plan

Maximum immunotherapy dose is applied at first, drug dose falls to $30 \mathrm{mg}$. Then it is closely monitored and increased gradually to $60 \mathrm{mg}$. Due to high dose of immunotherapy, vasculature cell volume falls drastically from $14000 \mathrm{~mm}^{3}$ to 
$6000 \mathrm{~mm}^{3}$ and then gradually decreased to $4000 \mathrm{~mm}^{3}$. Due to rapid destruction of vasculature cells, tumour cells do not get the opportunity to grow. The volume also reduced to $10000 \mathrm{~mm}^{3}$ from $12000 \mathrm{~mm}^{3}$ without any chemo application. Between $4^{\text {th }}$ and $5^{\text {th }}$ day maximum dose of chemo is applied and continued till end. At last tumour volume is also reduced to $9000 \mathrm{~mm}^{3}$.

Case 2: Maximum amount of chemo \& immunotherapy dose is applied at first, chemo dose is reduced to 0 after 2 days but immunotherapy is continued for 4 days. Figure 3 shows chemotherapy and immunotherapy drug doses and corresponding responses of tumour and vasculature cells with Case 2. Tumour cell volume is reduced rapidly to $75 \%$ within two days as an effect of chemotherapy and then gradually to $8000 \mathrm{~mm}^{3}$ due to continuation of immunotherapy. Vasculature cell volume reduces to $5000 \mathrm{~mm}^{3}$ from $14000 \mathrm{~mm}^{3}$ due to both high chemo and immune dose. Then due to absence of chemo dose vasculature cell goes to the recovery phase.

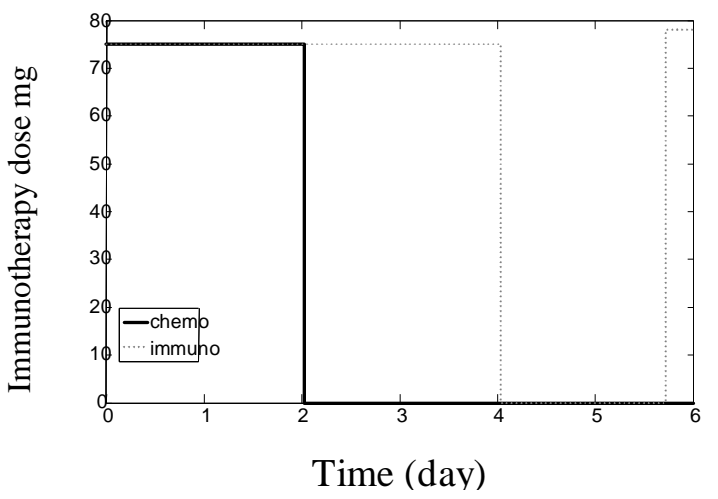

(a)

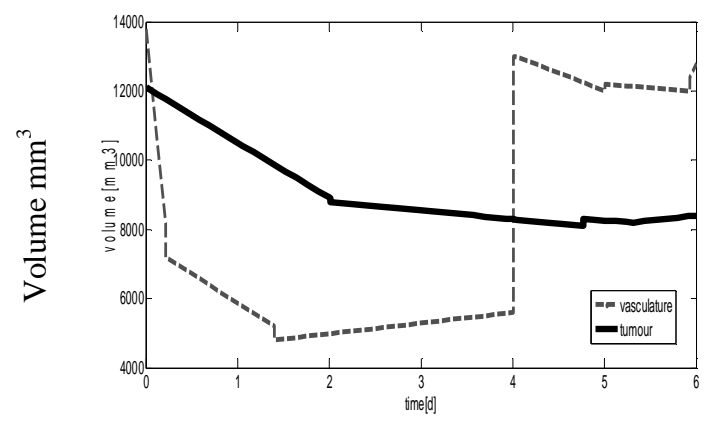

Time (day)

(b)

Fig. 3. (a) Chemotherapy and Immunotherapy drug doses, (b) Response of cells with Case 2 treatment plan

Case 3: Figure 4 shows chemotherapy and immunotherapy drug doses and corresponding responses of tumour and vasculature cells with Case 3. Vasculature cell volume is decreased from $14000 \mathrm{~mm}^{3}$ to $7500 \mathrm{~mm}^{3}$ i.e. about $50 \%$ of its initial value very rapidly and then gradually decreased more than $30 \%$. Tumour cell volume also reduced slightly due to immuno therapy effect. When high dose of chemotherapy is applied there is a rapid reduction to $4000 \mathrm{~mm}^{3}$, about $67 \%$ reduction is achieved.

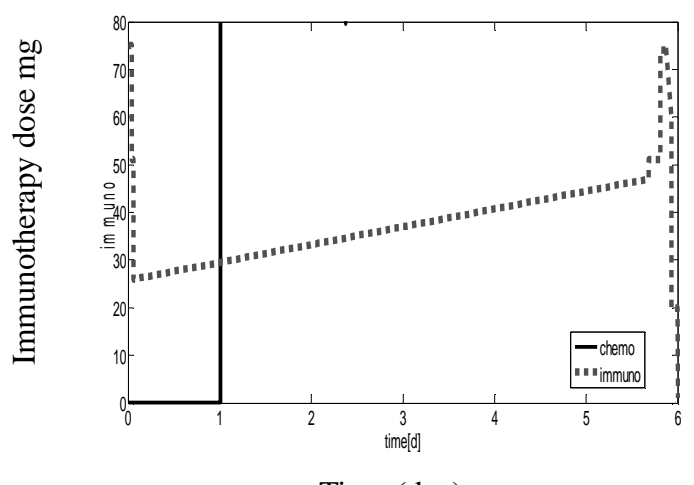

Time (day)

(a)

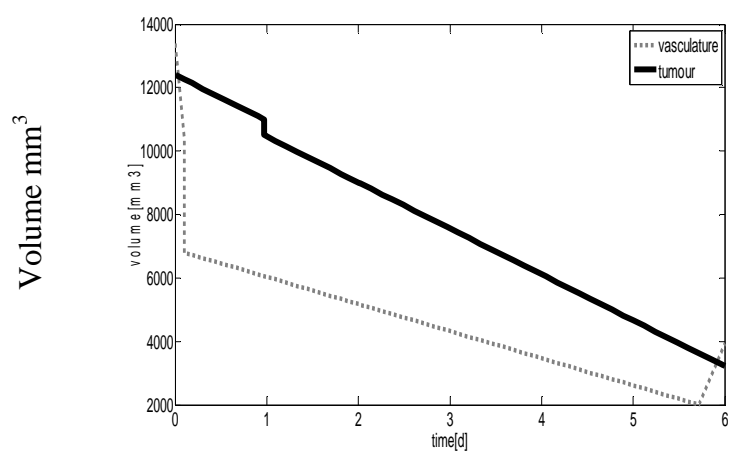

Time (day)

(b)

Fig. 4. (a) Chemotherapy and Immunotherapy drug doses, (b) Response of cells with Case 3 treatment plan

Case 4: Figure 5 shows chemotherapy and immunotherapy drug doses and corresponding responses of tumour and vasculature cells with Case 4 treatment plan. Immunotherapy dose is increased to $25 \mathrm{mg}$ at the very beginning of the treatment and then gradually increased up to $50 \mathrm{mg}$. Prior to immunotherapy the vasculature cell volume is increased from $5000 \mathrm{~mm}^{3}$ to $9000 \mathrm{~mm}^{3}$ and then decreased from $9000 \mathrm{~mm}^{3}$ to $4000 \mathrm{~mm}^{3}$ as the response of immunotherapy-reduction rate is $55 \%$. Such a reduction of vasculature cell also causes the reduction of tumour cell volume from $14000 \mathrm{~mm}^{3}$ to $11000 \mathrm{~mm}^{3}$ i.e. $22 \%$ reduction without any chemotherapy. Then before 2 days of the cycle the maximum dose of chemotherapy is applied and cancerous cell volume reduces to $8000 \mathrm{~mm}^{3}$ which is $56 \%$ of the initial value. It means another $22 \%$ reduction in 2 days for maximum chemo dose. At the end 
immunotherapy is decreased to zero to facilitate vasculature cell reproduction.

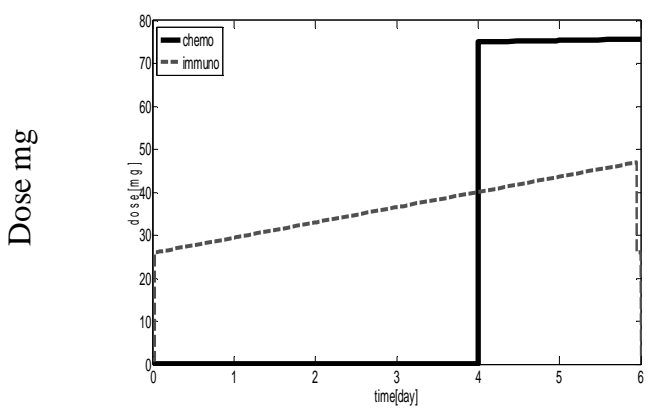

Time (day)

(a)

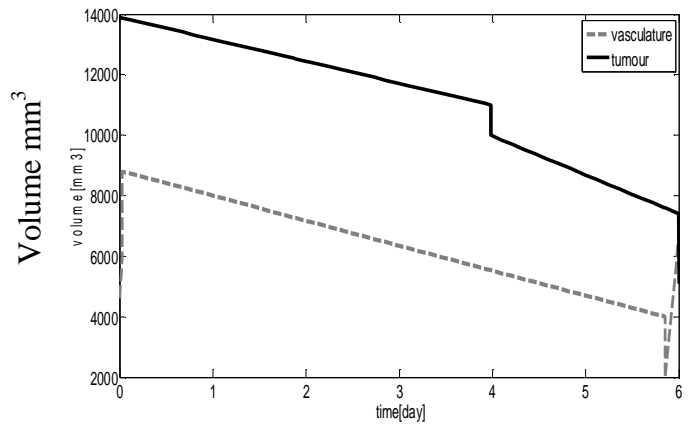

Time (day)

(b)

Fig. 5. (a) Chemotherapy and Immunotherapy drug doses, (b) Response of cells with Case 4 treatment plan.

Case 5: In this case, immunotherapy dose is increased to $25 \mathrm{mg}$ at the very beginning of the treatment and then gradually increased up to 50mg. Figure 6 shows chemotherapy and immunotherapy drug doses and corresponding responses of tumour and vasculature cells with Case 5.

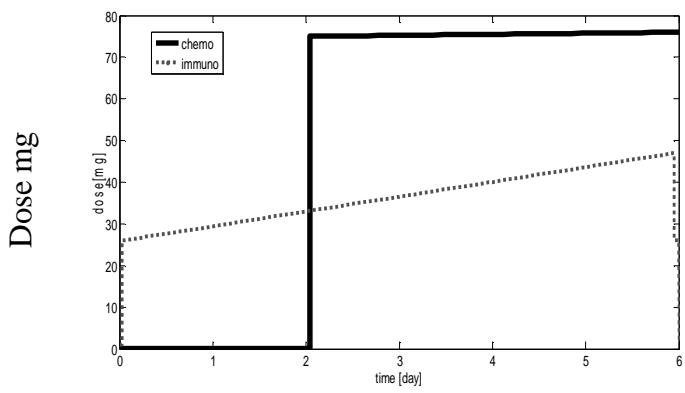

Time (day)

(a)

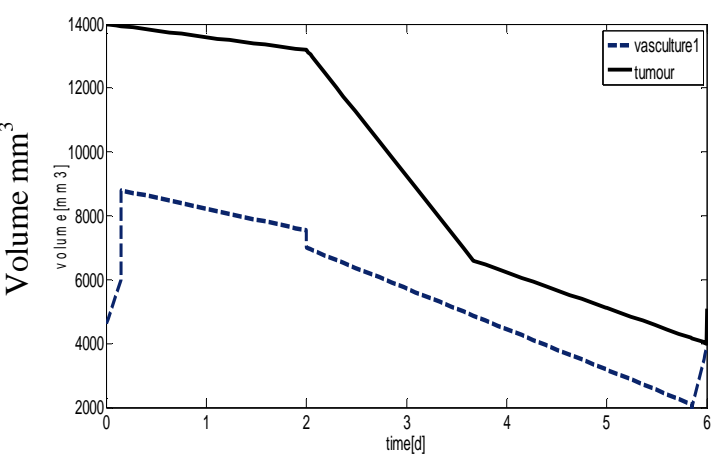

Time (day)

(b)

Fig. 6. (a) Chemotherapy and Immunotherapy drug doses, (b) Response of cells with Case 5 treatment plan.

The vasculature cell volume reduction is $77 \%$. Then after 2 days the maximum dose of chemotherapy is applied and cancerous cell volume reduces to $4000 \mathrm{~mm}^{3}$ which is $28 \%$ of the initial value. At the end immunotherapy is decreased to zero to facilitate vasculature cell recovery phase.

Case 6: Figure 6 shows chemotherapy and immunotherapy drug doses and corresponding responses of tumour and vasculature cells with Case 6. It is observed that, cancerous cell volume reduces from $12000 \mathrm{~mm}^{3}$ to $4000 \mathrm{~mm}^{3}$, i.e. reduction is about $67 \%$. Immunotherapy is decreased from $75 \mathrm{mg}$ to $50 \mathrm{mg}$ and then slowly increased up to $60 \mathrm{mg}$. Due to the high dose of both the therapy vasculature cell volume decreased from $14000 \mathrm{~mm}^{3}$ to $6000 \mathrm{~mm}^{3}$ : reduction is $57 \%$ at the beginning and finally reaches to $2000 \mathrm{~mm}^{3}$ i.e reduction is $87 \%$ from initial value. Such a reduction of vasculature cell also causes the rapid reduction of tumour cell volume. The end value of vasculature cell recovery is $4000 \mathrm{~mm}^{3}$. Performance measures of different treatment cases are summarized in Table 3.

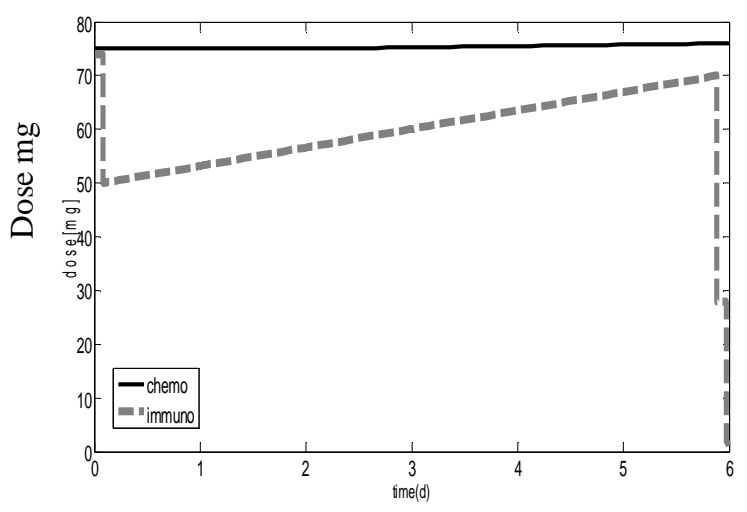

Time (day)

(a) 


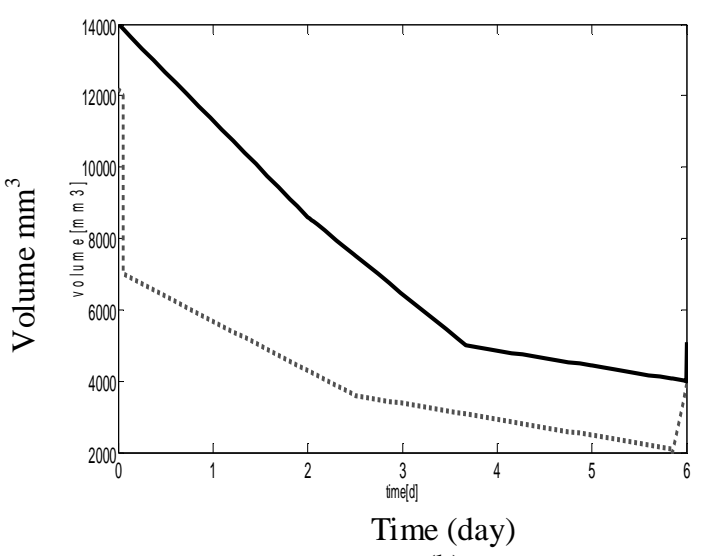

(b)

Fig. 7. (a) Chemotherapy and Immunotherapy drug doses, (b) Response of cells with Case 6 treatment plan

\section{Remarks}

In Case 3, there is a maximum reduction of tumour cell volume at the cost of high chemo dose. It also affects the vasculature cells to a great extent. Recovery to the normal state requires a long period. In case 4 , although reduction is $43 \%$, it requires $40 \%$ chemotherapy compared to Case 3. Vasculature cells are not too much and there is a normal increase of volume at the end compared to prior the treatment. So Case 4 can be considered most suitable to apply.

\section{Heuristically Design Drug Doses and Their Effects}

Since Case 4 delivers the best results, the scheduling can be modified to achieve even better response. Several combinations are tested and two more cases, namely, Case 7 and Case 8 , are presented in this section. In case 7, high dose of chemotherapy is applied between $2^{\text {nd }}$ and $3^{\text {rd }}$ day $\&$ then again between $4^{\text {th }}$ and $5^{\text {th }}$ day. For immunotherapy there is a gradual increase. In Case 7, cumulative chemotherapy and

Table. 3. Performance measures of different treatment cases

\begin{tabular}{|c|c|c|c|c|c|c|c|c|}
\hline Cases & $\begin{array}{l}\text { Cumulative } \\
\text { dose of } \\
\text { chemo } \\
\text { (mg) }\end{array}$ & $\begin{array}{l}\text { cumulative } \\
\text { dose of } \\
\text { immuno- } \\
\text { therapy } \\
\text { (mg) }\end{array}$ & $\begin{array}{l}\text { Tumour } \\
\text { cell volume } \\
\text { Prior to } \\
\text { treatment } \\
\left(\mathrm{mm}^{3}\right)\end{array}$ & $\begin{array}{l}\text { Tumour } \\
\text { cell volume } \\
\text { after treat- } \\
\text { ment }\left(\mathrm{mm}^{3}\right)\end{array}$ & $\begin{array}{l}\text { Percentage } \\
\text { of the } \\
\text { reduction }\end{array}$ & $\begin{array}{l}\text { Vasculature } \\
\text { cell } \\
\text { volume Prior } \\
\text { to treatment } \\
\left(\mathrm{mm}^{3}\right)\end{array}$ & $\begin{array}{l}\text { Vasculature cell } \\
\text { volume after } \\
\text { treatment }\left(\mathrm{mm}^{3}\right)\end{array}$ & $\begin{array}{l}\text { Percentage } \\
\text { of he } \\
\text { change of } \\
\text { vasculature } \\
\text { cell }\end{array}$ \\
\hline Case 1 & 112.5 & 137 & 12000 & 9000 & $42 \%$ & 14000 & 8000 & $-42.85 \%$ \\
\hline Case 2 & 150 & 400 & 12000 & 8000 & $34 \%$ & 14000 & 12000 & $-14.28 \%$ \\
\hline Case 3 & 375 & 139 & 12000 & 4000 & $67 \%$ & 14000 & 4000 & $-72 \%$ \\
\hline Case 4 & 150 & 190 & 14000 & 8000 & $43 \%$ & 5000 & 8000 & $+60 \%$ \\
\hline Case 5 & 300 & 210 & 14000 & 4000 & $43 \%$ & 5000 & 4000 & $-20 \%$ \\
\hline Case 6 & 450 & 365 & 12000 & 4000 & $67 \%$ & 14000 & 4000 & $-72 \%$ \\
\hline
\end{tabular}

immunotherapy doses are $150 \mathrm{mg}$ and $313 \mathrm{mg}$ respectively. Figure 8 shows drug doses and response of model with Case 7. After the treatment period tumour volume decrease from $14000 \mathrm{~mm}^{3}$ to $6300 \mathrm{~mm}^{3}$. There is natural increase of vasculature cell volume from $6000 \mathrm{~mm}^{3}$ to $6500 \mathrm{~mm}^{3}$. It can be explained as, since there is a rest period of chemotherapy within the treatment schedule, it helps the antibody cells and vasculature cells to recovery from toxic effects of chemo medicine.

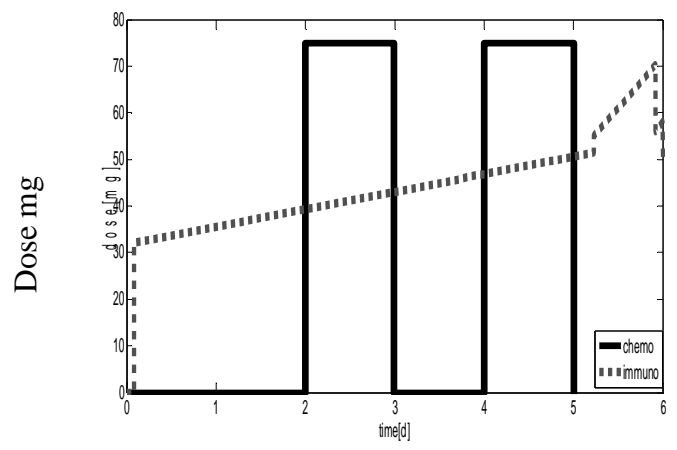

Time (day)

(a)

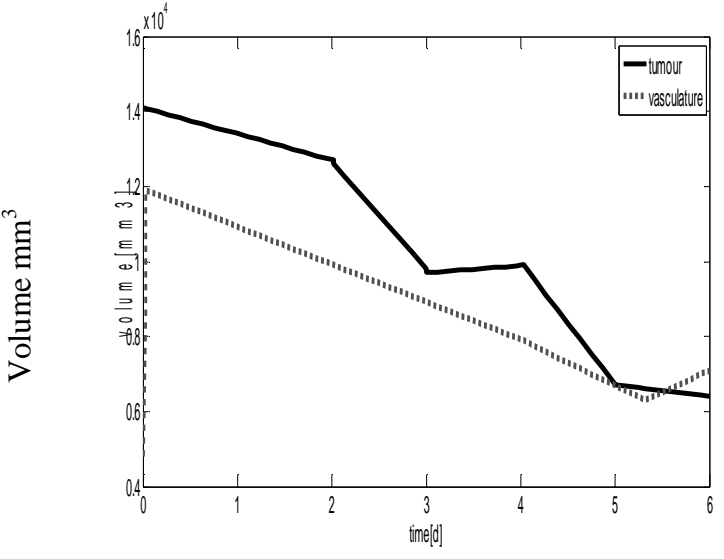

Time (day)

(b)

Fig. 8. (a) Chemotherapy and Immunotherapy drug doses, (b) Response of cells with Case 7 treatment plan.

Figure 9 shows drug doses and response of model with Case 8. Here high dose of chemotherapy is applied at first. Then there is a quick decrease between $1^{\text {st }}$ and $2^{\text {nd }}$ day. Then between $4^{\text {th }}$ 
and $5^{\text {th }}$ day there is a step wise decrease to zero. For immunotherapy there is a gradual increase. Cumulative chemotherapy and immunotherapy doses are $155 \mathrm{mg}$ and $313 \mathrm{mg}$ respectively. After the treatment period tumour volume decrease from $14000 \mathrm{~mm}^{3}$ to $4000 \mathrm{~mm}^{3}$ and vasculature cell volume are reduced from $4000 \mathrm{~mm}^{3}$ to $7000 \mathrm{~mm}^{3}$. All results are shown in Table 4. From Table 4, it is observed that for a fixed immunotherapy by applying a well scheduled chemotherapy it is possible to obtain maximum amount of reduction of tumour volume with very little effect on normal body cell. In Case 8, chemotherapy is $40 \mathrm{mg}$ lower than the first case but tumour volume is reduced $18 \%$ more because of well scheduling. At the same time vasculature cell volume is in increasing trend by a well margin showing better recovery.

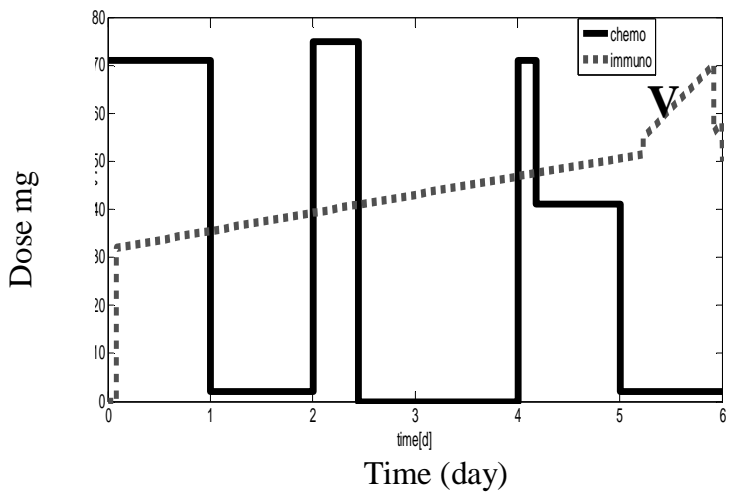

(a)

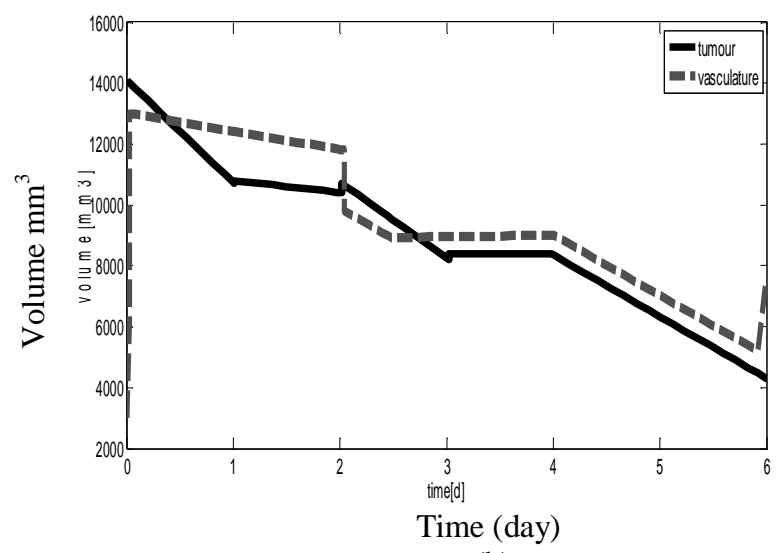

(b)

Fig. 9. (a) Chemotherapy and Immunotherapy drug doses, (b) Response of cells with Case 8 treatment plan.

\section{Parameter Sensitivity}

In preceding sections, optimum values of three parameters; (i) growth speed of the cancer cells $(E)$, (ii) cells killed per unit time per unit drug concentration $(\emptyset)$, and (iii) carrying capacity of vasculature cells(b), as indicated in Table 1, are used. It is also noted that, values of parameters remained unchanged for the whole period to observe the effectiveness of drugs on cancer tumour. It may be mentioned that the predefined set of parameters correspond to a specific physiological condition and drug type under investigation.

Table. 4. Performance measures of different Cases

\begin{tabular}{|l|c|c|c|c|c|c|c|c|}
\hline Cases & $\begin{array}{c}\text { Cumulative } \\
\text { dose of } \\
\text { chemo } \\
(\mathrm{mg})\end{array}$ & $\begin{array}{c}\text { cumulative } \\
\text { dose of } \\
\text { immuno- } \\
\text { therapy } \\
(\mathrm{mg})\end{array}$ & $\begin{array}{c}\text { Tumour } \\
\text { cell } \\
\text { volume } \\
\text { prior to } \\
\text { treatment } \\
\left(\mathrm{mm}^{3}\right)\end{array}$ & $\begin{array}{c}\text { Tumour } \\
\text { cell } \\
\text { volume } \\
\text { after treat- } \\
\text { ment } \\
\left(\mathrm{mm}^{3}\right)\end{array}$ & $\begin{array}{c}\text { Percenta } \\
\text { ge } \\
\text { of } \\
\text { reduction }\end{array}$ & $\begin{array}{c}\text { Vasculature } \\
\text { cell } \\
\text { volume } \\
\text { prior to } \\
\text { treatment } \\
\left(\mathrm{mm}^{3}\right)\end{array}$ & $\begin{array}{c}\text { Vasculature } \\
\text { cell } \\
\text { volume after } \\
\text { treatment } \\
\left(\mathrm{mm}^{3}\right)\end{array}$ & $\begin{array}{c}\text { Percentage } \\
\text { of } \\
\text { change of } \\
\text { vasculature } \\
\text { cell }\end{array}$ \\
\hline Case 7 & 150 & 313 & 14000 & 6300 & $55 \%$ & 6000 & 6500 & $+10 \%$ \\
\hline Case 8 & 155 & 313 & 14000 & 4000 & $71.43 \%$ & 4000 & 7000 & $+75 \%$ \\
\hline
\end{tabular}

Further investigations are carried out in this section to analyze the sensitivity of the aforementioned three parameters of d'Onofrio et al. model. A particular treatment plan (Case 4) is administered on the tumour model with different values of parameters and output responses of the model, are recorded and analyzed.

At first, the parameter (E), is varied within a range of $[0.07,0.1]$ while setting the remaining parameters at optimum values and results are shown in Table 5. The maximum tumour cell reduction is obtained with 0.07 which is reduced from $15000 \mathrm{~mm}^{3}$ to $9000 \mathrm{~mm}^{3}$ i.e. $40 \%$. At the same time vasculature cell growth is also suppressed by tumour growth rate.
Table. 5. Effect of $(E)$ on tumour

\begin{tabular}{|c|c|c|c|}
\hline $\begin{array}{c}\text { Values of } \\
(\boldsymbol{\sigma})\end{array}$ & $\begin{array}{c}\text { upper } \\
\text { value of } \\
\text { tumour } \\
\left(\mathrm{mm}^{3}\right)\end{array}$ & $\begin{array}{c}\text { lower value } \\
\text { of tumour } \\
\left(\mathrm{mm}^{3}\right)\end{array}$ & $\begin{array}{c}\text { Percentage } \\
\text { of } \\
\text { reduction }\end{array}$ \\
\hline $\mathbf{0 . 0 7}$ & $\mathbf{1 5 0 0 0}$ & $\mathbf{8 0 0 0}$ & $\mathbf{4 7 \%}$ \\
\hline 0.08 & 15500 & 8500 & $45 \%$ \\
\hline 0.09 & 16000 & 9500 & $40 \%$ \\
\hline 1.0 & 16500 & 10000 & $39.4 \%$ \\
\hline
\end{tabular}

Secondly, the effect of model parameter: cells killed per unit time per unit drug concentration $(\emptyset)$ is analyzed in similar way. Here the parameter is varied within a range of $[0.115,0.085]$ 
while setting the remaining three parameters at optimum values. Different performance of tumour model due to the drug scheduling Case 4 and results are shown in Table 6 . It is noted that maximum cell reduction is obtained with $\emptyset$ $=0.115$ where the volume of tumour remaining is $2000 \mathrm{~mm}^{3}$.

Table. 6. Effects of parameter $(\varnothing)$ on tumour

\begin{tabular}{|c|c|c|c|}
\hline $\begin{array}{c}\text { values } \\
\text { of }(\boldsymbol{\phi})\end{array}$ & $\begin{array}{c}\text { upper } \\
\text { value of } \\
\text { tumour } \\
\left(\mathrm{mm}^{3}\right)\end{array}$ & $\begin{array}{c}\text { lower value of } \\
\text { tumour }\left(\mathrm{mm}^{3}\right)\end{array}$ & $\begin{array}{c}\text { Percentage } \\
\text { of } \\
\text { reduction }\end{array}$ \\
\hline $\mathbf{0 . 1 1 5}$ & $\mathbf{1 5 0 0 0}$ & $\mathbf{2 0 0 0}$ & $\mathbf{8 7 \%}$ \\
\hline 0.09 & 15000 & 4000 & $73 \%$ \\
\hline 0.085 & 150000 & 5000 & $66.6 \%$ \\
\hline 0.08 & 15000 & 6000 & $60 \%$ \\
\hline
\end{tabular}

Thirdly, the effect of model parameter: carrying capacity of vasculature cells(b) is also analyzed with treatment plan Case 4 where the parameter is varied in the range of $[0.2,0.145]$ and results are shown in Table 7 . The maximum tumour cell reduction is obtained with $b=0.2$, for which final volume of tumour is $1500 \mathrm{~mm}^{3}$.

Table. 7. Effects of parameter (b) on tumour

\begin{tabular}{|c|c|c|c|}
\hline $\begin{array}{c}\text { Values of } \\
(\mathrm{b})\end{array}$ & $\begin{array}{l}\text { upper value } \\
\text { of tumour } \\
\left(\mathrm{mm}^{3}\right)\end{array}$ & $\begin{array}{l}\text { lower value } \\
\text { of tumour } \\
\left(\mathrm{mm}^{3}\right)\end{array}$ & $\begin{array}{c}\text { Percentage } \\
\text { of } \\
\text { reduction }\end{array}$ \\
\hline 0.155 & 13000 & 3000 & $77 \%$ \\
\hline 0.180 & 12000 & 2500 & $79 \%$ \\
\hline 0.2 & 11500 & 1500 & $87 \%$ \\
\hline
\end{tabular}

\section{Conclusion}

This paper has presented a design and investigation into a mathematical model of cancer tumour response with chemotherapy and immunotherapy treatments. Optimal drug dosages and scheduling for chemotherapy and immunotherapy as designed by d'Onofrio and co-workers using several design objectives and constraints have been tested to observe the response of tumour during and after the treatment. Moreover, a number of dosages, both for chemotherapy and immunotherapy, have been designed based on heuristic method in the light of earlier dosages to improve the treatment further. It is observed that instead of applying a high dose for a long time, periodic application of high dose yields better results with regard to tumour volume reduction. The optimal treatment yields a tumour volume $71 \%$ smaller than the initial stage. In this paper an investigation into parameter sensitivity of the model has also been presented that helps to predict the effect of drugs on different types of cancer cell as well as effect of different types of drugs on tumour and vasculature cells.
1. d'Onofrio and A. Gandolfi, "The response to antiangiogenic anticancer drugs that inhibit endothelial cell proliferation", Applied Mathematical Computation. pp.181-187,10, 2006.

2. d'Onofrio, U. Ledzewicz, H. Maurer and H. Schaettler, "An optimal delivery of combination therapy for tumours", Mathematical Bioscience, pp. 222-225, 13, 2009.

3. Engelhart, M., D. Lebiedz and S.Sager, "Optimal control for selected cancer chemotherapy ODE models: A view on the potential of optimal schedules and choice of objective function", Journal of Mathematical Biosciences, pp.123-134, 22(9), 2011.

4. de Pillis, L., W.Gu, and A.Radunskaya, "Mixed immunotherapy and chemotherapy of tumors: modeling, applications and biological interpretations", Journal of Theoretical Biology. pp. 238-241, 4, 2006.

5. Chaplain, L., W.Gu, and A.Radunskaya, "Mixed immunotherapy and chemotherapy of tumors: modeling, applications and biological interpretations", Journal of Theoretical Biology, pp.238-243, 841, 2006.

6. Martin, R. and K. L. Teo, "Optimal control of drug administration in chemotherapy tumour Growth", World Scientific, pp. 1-10, 1,1994.

7. Algoul, S., M.S. Alam, M.A. Hossain, and M.A. Majumder, "Multi-objective Optimal Chemotherapy Control Model for Cancer Treatment", Springer Journal on Medical and Engineering and Computing; ISSN-1741-0444, 49(1), pp. 51-65, 2010, DOI: 10.1007/s11517-010-0678-y, Springer Verlag, Berlin.

8. Algoul, S., M.S. Alam, K. Sakib, M.A. Hossain, and M.A. Majumder, "Feedback Control of Chemotherapy Drug Scheduling for Phase Specific Cancer Treatment", The IEEE Fifth International Conference on Bio-Inspired Computing: Theories and Applications (BIC-TA 2010), pp. 1443-1450, Liverpool, UK, September 8-10, 2010.

9. Alam M.S, S. Algoul, M.A. Hossain and M.A. Majumder, "Multi-objective Particle Swarm Optimisation for Phase Specific Cancer Drug Scheduling", Communications in Computer and Information Science, Volume 115, pp. 180-192, 2010, DOI: 10.1007/978-3-642-16750-8, Springer Verlag, Berlin,

10. Hahnfeldt, P., D. Panigraphy, J. Folkman, L. Hlatky, "Tumour development under angiogenic signaling: a dynamical theory of tumour growth, treatment response, and postvascular dormancy”, Cancer Res. 59, 4770, 1999.

11. The Mathworks, (2010) MATLAB Reference Guide. 
Dhaka Univ. J. Sci. 60(2): 1-6, 2012 (July)

*Author for correspondence 